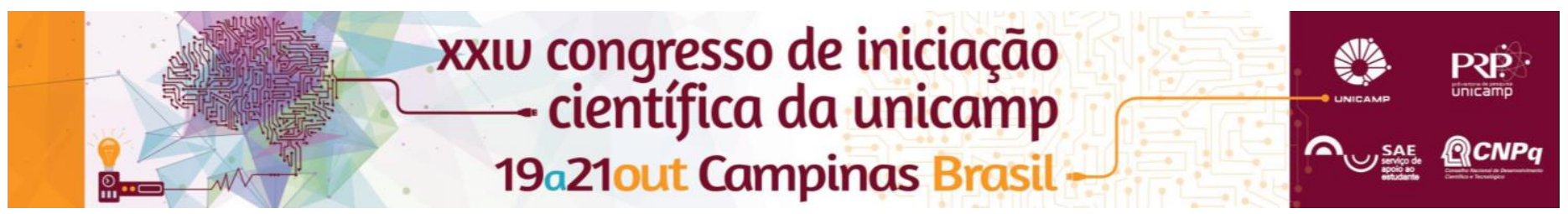

\title{
Eficácia de diferentes agentes químicos para o controle microbiano nas mãos e nas superfícies.
}

\section{Bruno Sotopietro; Dandara Reame da Silva; Maria Thereza Ferreira Rocha; Felipe Joia; Josianne Neres; Talita Signoreti Graziano; Rafael Nobrega Stipp}

\section{Resumo}

O aparecimento de infecções nos ambientes de assistência à saúde pode estar relacionado ao uso de técnicas incorretas de limpeza e desinfecção de superfícies. Portanto, avaliamos a eficácia antimicrobiana dos produtos indicados para a limpeza e desinfecção das superfícies e assepsia das mãos contra o microrganismo Pseudomonas aeruginosa. Foram testados 15 produtos indicados na utilização em clínicas médicas e odontológicas. A cultura bacteriana foi adicionada na placa de petri, espalhada e mantida em temperatura ambiente para secagem da superfície. Os produtos foram aplicados e após 5 minutos foi feita a raspagem e coleta do conteúdo da placa, e transferidos para uma placa de $\mathrm{BHI}$-ágar para a contagem dos microrganismos. A maioria dos produtos se mostrou capaz de eliminar a totalidade do microrganismo.

\section{Palavras-chave:}

Microbiologia, Degermante e Bacterecida.

\section{Introdução}

A desinfecção de superfícies e assepsia das mãos em serviços de saúde são formas de controle biológico que rompem a cadeia epidemiológica das infecções, proporcionando o bem-estar, a segurança e o conforto dos pacientes e profissionais. Eles são procedimentos fundamentais para manter a biossegurança nos consultórios odontológicos.

\section{Resultados e Discussão Agentes químicos testados}

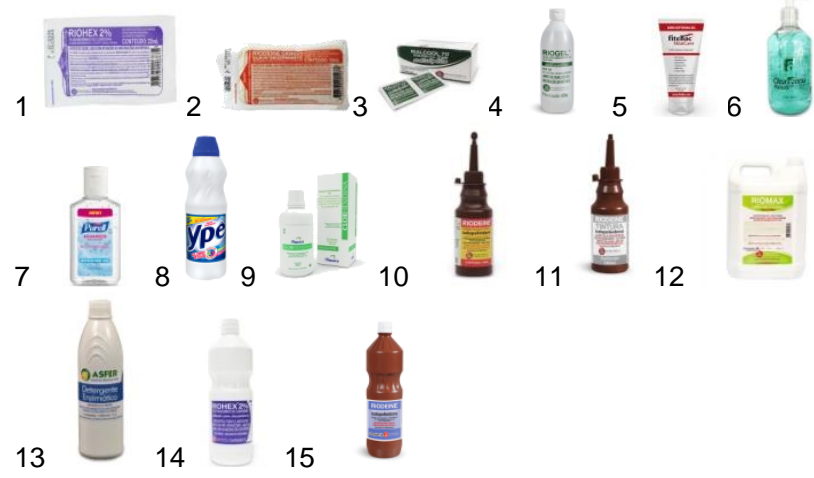

1- Marclorhex"-Escova de Clorexidina $2 \%$

2- Marcodine"-Escova de Iodopovidona $100 \mathrm{mg} / \mathrm{ml}$

3- Rialcool 70" - Álcool etílico 770 GL

4- Riogel" -Álcool etílico hidratado $70 \% \mathrm{v} / \mathrm{v}$

5- FiteBac SkinCare Hand Softening Gel

6- CleanForm Hands-Álcool $70 \%$ Gel (Aloe vera)

7- Purell Advanced Hand Sanitizer

8- Água sanitária Ypê (2\%)

9- Solução de Clorexidina $2 \%$

10- Riodeine" dermo suave tópico - 10\% iodopolividona

11- Riodeine" tintura-10\% iodopolividona

12- Riomax"-sabonete líquido com glicerina

13- Detergente enzimático

14- Riodeine" dermo suave degermante- $10 \%$ iodopolividona

15- Riohex"0,5\% - digliconato de clorexidina $0,5 \%$

DOI: 10.19146/pibic-2016-51301
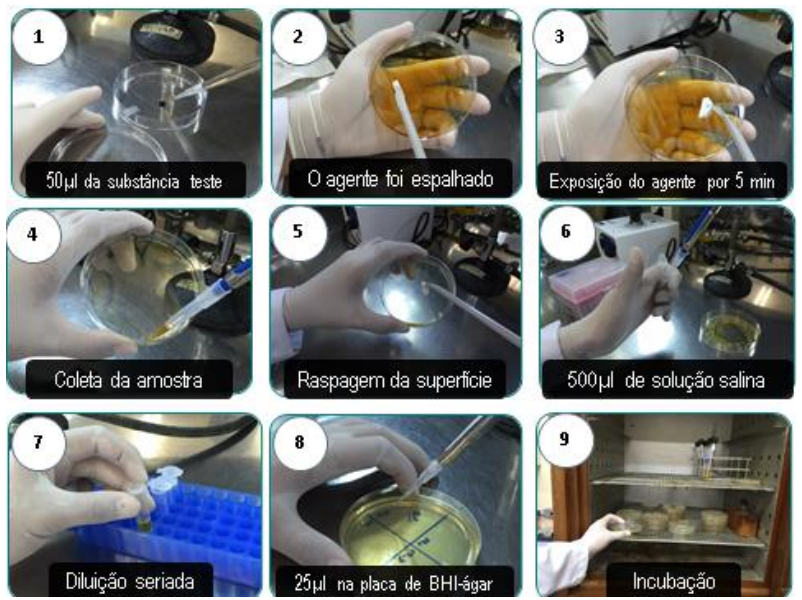

\section{Poder bactericida (\%)}

Riodeine回 dermo suave degermante Riohex@ $0,5 \%$ - digliconato de clorexidina Detergente enzimático Riomax回- sabonte líquido com glicerina Riodeine@ tintura - $10 \%$ iodopolividona Riodeine@ dermo suave tópico - $10 \%$ Solução de Clorhexidina $2 \%$ Água sanitaria Y pê (2\%) Purell Advanced Hand Sanitizer CleanForm Hands - Álcool 70\% Gel (Áloe FiteBac SkinCare Hand Softening Gel Rioge日) - Álcool etílico hidratado 70 wo Rialcool 70@ - Álcool etílico $77^{\circ} \mathrm{GL}(120$ Marcodine间- lodopovidona $100 \mathrm{mg} / \mathrm{ml}$ Marclorhex@-Digliconato de clorexidina

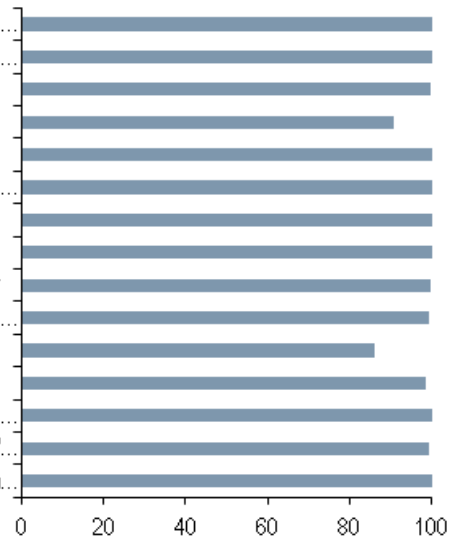

\section{Conclusões}

Todos os agentes testados demonstraram atividade microbiana acima de $80 \%$. A maioria eliminou a totalidade dos microrganismos. Portanto, os agentes químicos se mostram adequados para o uso em atividades clínicas.

\section{Agradecimentos}

A instituição da FOP-Unicamp, ao nosso orientador Rafael Nobrega Stipp e ao professor Miguel Morano Junior, por proporcionarem grande aprendizado no período de 2015/2016. 